\title{
PENGARUH PENDIDIKAN KESEHATAN TENTANG HIPERTENSI DAN PROGRAM LATIHAN TERPADU TERHADAP PERILAKU LANSIA DALAM PENGENDALIAN HIPERTENSI DI DUSUN KARANGANOM DESA SERUT KECAMATAN PANTI KABUPATEN JEMBER
}

\section{(THE EFFECT OF AN INTEGRATED HELATH EDUCATION AND EXERCISE PROGRAM ON ELDERLY BEHAVIOR IN HYPERTENSION CONTROL)}

\author{
Yudha Jatmika ${ }^{1}$, Puspa Fitriyana ${ }^{2}$, Jamilatul Komari ${ }^{3}$, Chairun Nisak ${ }^{4}$, Novaria \\ Puspitasari $^{5}$, Novita Nurkamilah ${ }^{6 *}$, Siti Aisyah Asri ${ }^{7}$, Mayangga Sukmawati ${ }^{8}$, \\ Hanny Rasni ${ }^{9}$ \\ Fakultas Keperawatan Universitas Jember \\ J1. Kalimantan No. 37 Kampus Tegal Boto Jember Telp./Fax. (0331) 323450 \\ *e-mail: novita.nurkamilah.28@gmail.com
}

\begin{abstract}
ABSTRAK
Lanjut usia sangat erat hubungannya dengan terjadinya hipertensi. Penatalaksanaan hipertensi dapat dilakukan secara farmakologi dan non farmakologi. Salah satu penatalaksanaan non farmakologi yaitu dengan pemberian edukasi dan olahraga/latihan secara rutin. Penelitian ini bertujuan menganalisa pengaruh pendidikan kesehatan tentang hipertensi dan program latihan terpadu terhadap perilaku lansia dalam pengendalian hipertensi. Penelitian ini menggunakan metode quasi experimental dengan desain penelitian pre-test and post-test with control group design. Dua puluh responden dalam penelitian ini dibagi menjadi 10 responden sebagai kelompok intervensi dan 10 responden sebagai kelompok kontroll dengan teknik consequtive sampling. Pendidikan kesehatan diberikan selama 4 sesi, kemudian diberikan program latihan senam antihipertensi setiap minggu selama 4 kali. Data dianalisis menggunakan uji $t$ dependen dengan taraf signifikansi 0,05. Hasil uji $t$ dependen menunjukkan perbedaan signifikan perilaku lansia antara pretest dan posttest pada kelompok intervensi $(\mathrm{p}=0,001)$, sedangkan pada kelompok kontrol didapatkan $\mathrm{p}=0,560$. Selanjutnya, uji $\mathrm{t}$ independen menunjukkan adanya perbedaan signifikan antara kelompok intervensi dan kelompok kontrol $(\mathrm{p}=0,001)$. Hasil penelitian ini menunjukkan bahwa terdapat pengaruh signifikan pendidikan kesehatan tentang hipertensi dan program latihan terpadu terhadap perilaku lansia dalam pengendalian hipertensi. Perawat khususnnya perawat komunitas diharapkan menerapkan program tersebut sebagai acuan untuk meningkatkan perilaku lansia dalam pengendalian hipertensi.

Kata kunci: pendidikan kesehatan, latihan, perilaku lansia, hipertensi
\end{abstract}

\section{ABSTRACT}

Elderly is very related to the occurrence of hypertension. Management of hypertension can be done pharmacologically and nonpharmacologically. One of non pharmacology management is by giving education and exercise regularly. This research aimed to analyze the effect of an integrated helath education and exercise program on elderly behavior in hypertension control. This research was quasi experimental with non randomized control group pretest posttest design. Twenty respondents in this study were divided into 10 respondents as the intervention group and 10 respondents as the control group by consequtive sampling technique. Health education was conducted in 4 sessions, then give antihypertention gymnastic training program every week for 4 times. The data were analyzed by using dependent $t$ test and independent $t$ test with significance level of 0.05 . The result of $t$ 
dependent test showed significant difference of elderly behavior between pretest and posttest in intervention group $(p=0,001)$, while in control group obtained $p=0,560$. Furthermore, independent $t$ test showed a significant difference between intervention group and control group ( $p=0.001)$. The results of this study indicates that there is a significant effect of health education on hypertension and integrated exercise program on elderly behavior in hypertension control. Special community nurses are expected to implement this program as a reference to improve elderly behavior in the control of hypertension.

Keywords: health education, exercise, elderly behavior, hypertension

\section{PENDAHULUAN}

Lanjut usia akan mengalami penurunan fungsi tubuh akibat perubahan fisik, psikososial, kultural, spiritual. Perubahan fisik akan mempengaruhi berbagai system tubuh salah satunya adalah system kardiovaskuler. Masalah kesehatan akibat dari proses penuaan dan sering terjadi pada sistem kardiovaskuler yang merupakan proses degeneratif, diantaranya yaitu penyakit hipertensi (Herlinah, dkk., 2013). Menurut Kellicker (2010) menyatakan bahwa hipertensi pada lansia merupakan suatu keadaan yang ditandai dengan hipertensi sistolik diatas $140 \mathrm{mmHg}$ dan diastoliknya menetap atau kurang dari 90 $\mathrm{mmHg}$ yang memberi gejala yang berlanjut, seperti stroke, penyakit jantung coroner.

Data kejadian hipertensi tahun 2013 dengan menggunakan unit analisis individu menunjukkan bahwa secara nasional $25,8 \%$ penduduk Indonesia menderita penyakit hipertensi. Jumlah penduduk yang menderita hipertensi terus berkembang dari 600 juta pada tahun 1980 menjadi 1 milyar jiwa pada tahun 2008 (WHO,2013). Prevalensi hipertensi di Indonesia sebesar 26,5\%. Prevalensi hipertensi di Jawa Timur didapatkan sebesar 26,2\% (Riskesdas, 2013)

Berdasarkan hasil penjajakan di Desa Serut Kecamatan Panti Kabupaten Jember didapatkan 133 lansia. Rata-rata lansia mengeluhkan hipertensi. Berdasarkan wawancara dengan lansia yang mengalami hipertensi pada tanggal 6 Mei 2018 di Dusun Krajan Desa Serut Kecamatan Panti Kabupaten Jember menyatakan bahwa mereka sudah berusaha memperhatikan lansia dengan cara mengingatkan aturan makanan yang berisiko terjadi hipertensi seperti menyiapkan makanan rendah lemak dan mengurangi garam pada makanannya, serta membedakan makanan istrinya dengan makanannya terkait banyaknya pemberian garam. Namun lansia masih belum tahu cara pengolahan makanan yang benar. Selain itu, lansia tersebut masih kurang memahami perawatan hipertensi dan apa saja yang harus dilakukan untuk mengendalikan hipertensi.

Tingkat pendidikan, komunikasi dan informasi kebudayaan, dan pengalaman pribadi seseorang akan mempengaruhi pengetahuan dan sikap dan perilaku tentang kesehatan. Dengan mendapatkan infomasi yang benar, diharapkan lansia mendapat bekal pengetahuan yang cukup untuk dapat melaksanakan pola hidup sehat dan dapat menurunkan risiko penyakit degeneratif terutama hipertensi dan penyakit kardiovaskular (Notoatmodjo, 2003).

Posyandu lansia adalah pos pelayanan terpadu untuk masyarakat usia lanjut di suatu wilayah tertentu yang sudah disepakati, yang digerakkan oleh masyarakat dimana mereka bisa mendapatkan pelayanan kesehatan. Penelitian tentang hipertensi pada lansia dilaksanakan di Posyandu Lansia di Dusun Karanganom Desa Serut Kecamatan Panti Kabupaten Jember yang, mengacu pada teori bahwa tekanan darah akan meningkat pada orang tua oleh karena penyakit degeneratif. Berdasarkan hal tersebut peneliti tertarik dan terdorong untuk mengadakan penelitian Pengaruh Pendidikan Kesehatan tentang Hipertens dan Program Latihan terhadap Perilaku Lansia dalam Pengendalian Hipertensi di 
Dusun Karanganom Desa Serut Kecamatan Panti Kabupaten Jember.

Menurut WHO (1999) dalam Aspiani (2014) mengelompokkan usia lanjut berdasarkan usia biologis dibagi menjadi empat kelompok yaitu usia pertengahan (middle age) antara usia 45-59 tahun, lanjut usia (elderly) berusia antara 60-74 tahun, lanjut usia tua (old) berusia 75-90 tahun, dan usia sangat tua (very old) berusia $>90$ tahun.

Tujuh kategori utama tugas perkembangan lansia meliputi (Potter \& Perry, 2005): menyesuaikan terhadap penurunan kekuatan fisik dan kesehatan, menyesuaikan terhadap masa pensiun dan penurunan pendapatan, menyesuaikan terhadap kematian pasangan, menerima diri sendiri sebagai individu lansia, mempertahankan kepuasan pengaturan hidup, mendefinisikan ulang hubungan dengan anak yang dewasa, dan menentukan cara untuk mempertahankan kualitas hidup.

Semakin bertambahnya umur manusia, terjadi proses penuaan secara degeneratif yang akan berdampak pada perubahan-perubahan berupa fisik, tetapi juga kognitif, perasaan, sosial dan seksual (Azizah, 2011).

Aspiani (2014), menyatakan mengenai kondisi kesehatan lansia mengenai penyakit yang sering dialami salah satunya adalah hipertensi. Menurut Joint National Committee 8 (2013), hipertensi terjadi apabila tekanan darah lebih dari 140/90 mmHg. Hipertensi adalah suatu keadaan dimana terjadi peningkatan tekanan darah secara abnormal dan terus menerus pada beberapa kali pemeriksaan tekanan darah yang disebabkan satu atau beberapa faktor risiko yang tidak berjalan sebagaimana mestinya mempertahankan tekanan darah secara normal (Wijaya, 2013).

Penatalaksanaan hipertensi dapat dilakukan secara farmakologi dan non farmakologi. Beberapa penelitian menunjukkan bahwa pendekatan nonfarmakologis, dengan modifikasi gaya hidup seperti teknik-teknik mengurangi stress, penurunan berat badan, pembatasan alkohol, olahraga/latihan, relaksasi merupakan intervensi wajib yang harus dilakukan pda setiap terapi antihipertensi. Modifikasi gaya hidup merupakan hal yang sulit bagi individu karena harus mengubah kebiasaan yang menyenangkan (Potter \& Perry, 2009).

\section{METODE}

Penelitian ini menggunakan desain quasi experimental dengan desain penelitian pre-test and post-test with control group design. Sampel penelitian yaitu 20 lansia yang terbagi menjadi 10 lansia dalam kelompok kontrol dan 10 lansia kelompok intervensi. Sampel penelitian diambill sesuai dengan yang memenuhi kriteria inklusi. Kriteria inklusi yaitu lansia yang terdiagnosis hipertensi, berusia 50-75 tahun, lansia bugar, anggota lansia yang teratur posyandu lansia, dan bersedia menjadi responden. Kriteria eksklusi dalam penelitian ini yaitu lansia yang mengalami komplikasi penyakit dari hipertensi, lansia yang tidak memungkinkan untuk melakukan senam, mengundurkan diri pada saat penelitian, dan yang tidak mengikuti program sampai selesai.

Teknik sampel yang digunakan adalah consecutive sampling. Pengambilan data dalam penelitian ini dilaksanakan di Dusun Karanganom Desa Serut Kecamatan Panti Kabupaten Jember bulan Mei tahun 2018 dengan membagikan kuesioner pretest sebelum dilakukan perlakuan kemudian setelah diberikan perlakuan dilakukan pengukuran posttest untuk mengetahui akibat dari perlakuan tersebut. Kuesioner penelitian ini telah di Uji validitas dan Uji reliabilitas dengan hasil yang didapatkan yaitu nilai $r$ tabel $>$ 0,800 sehingga dinyatakan valid. Intervensi yang diberikan berupa pendidikan kesehatan tentang hipertensi selama 4 sesi, setelah itu diberikan program latihan rutin yaitu senam antihipertensi yang dilakukan selama 4 
kali dalam sebulan.

HASIL

Usia Responden

Tabel 1. Distribusi Usia Resonden

\begin{tabular}{lccc}
\hline \multicolumn{1}{c}{ Variabel } & Mean & SD & $\begin{array}{c}\text { Min- } \\
\text { Maks }\end{array}$ \\
\hline $\begin{array}{l}\text { Usia (tahun) } \\
\text { Kelompok } \\
\text { perlakuan } \\
(\mathrm{n}=15)\end{array}$ & 63,20 & 5,865 & $55-72$ \\
$\begin{array}{l}\text { Kelompok } \\
\text { kontrol }(\mathrm{n}=15)\end{array}$ & 64,10 & 8,346 & $52-75$ \\
\hline
\end{tabular}

Tabel 1 menunjukkan Rata-rata usia responden kelompok perlakuan yaitu 63,20 tahun, sedangkan rata-rata usia responden kelompok kontrol yaitu 64,10 tahun. Usia responden paling muda yaitu 52 tahun dan paling tua 75 tahun.

\section{Jenis kelamin Responden}

Tabel 2. Distribusi Jenis Kelamin Responden

\begin{tabular}{lcccc}
\hline & \multicolumn{2}{c}{$\begin{array}{c}\text { Kelompok } \\
\text { Variabel }\end{array}$} & \multicolumn{2}{c}{$\begin{array}{c}\text { Kelompok } \\
\text { Kontrol }\end{array}$} \\
\cline { 2 - 5 } & Jumlah & $\%$ & $\begin{array}{c}\text { Jumla } \\
\mathrm{h}\end{array}$ & $\%$ \\
\hline Jenis & & & & \\
Kelamin & & & & \\
Laki-laki & 1 & 10 & 3 & 30 \\
Perempua & 9 & 90 & 7 & 70 \\
$\mathrm{n}$ & & & & \\
\hline Total & 10 & 100 & 10 & 100 \\
\hline
\end{tabular}

Tabel 2 menunjukkan responden kelompok perlakuan memiliki jumlah perempuan lebih banyak dibandingkan laki-laki, yaitu laki-laki 1 orang (10\%) dan perempuan 9 orang (90\%). Kelompok kontrol memilki jumlah peremuan lebih banyak dibandingkan dengan laki-laki, yaitu perempuan sebanyak 3 orang (30\%) dan laki-laki sebanyak 7 orang $(70 \%)$.

\section{Pendidikan Responden}

Tabel 3. Distribusi Pendidikan Responden

\begin{tabular}{lcccc}
\hline \multirow{2}{*}{ Variabel } & \multicolumn{2}{c}{$\begin{array}{c}\text { Kelompok } \\
\text { perlakuan }\end{array}$} & \multicolumn{2}{c}{$\begin{array}{c}\text { Kelompok } \\
\text { Kontrol }\end{array}$} \\
\cline { 2 - 5 } & Jumlah $\%$ & Jumlah $\%$ \\
\hline Pendidikan & & & & \\
Tidak sekolah & 4 & 40 & 6 & 60 \\
SD Sederajat & 4 & 40 & 3 & 30 \\
SMP Sederajat & 2 & 20 & 1 & 10 \\
\hline Total & 10 & 100 & 10 & 100 \\
\hline
\end{tabular}

Tabel 3 menunjukkan pendidikan responden kelompok perlakuan sama besar antara tidak sekolah dan SD sederajat yaitu sebanyak 4 responden (40\%), sedangkan pendidikan responden kelompok kontrol sebagian besar adalah tidak sekolah yaitu sebanyak 6 responden $(60 \%)$.

\section{Perilaku lansia dalam pengendalian hipertensi Kelompok Perlakuan}

Tabel 4. Perbedaan Nilai Peilaku lansia Sebelum dan Setelah Penkes dan Latihan

\begin{tabular}{cccccc}
\hline $\begin{array}{c}\text { Variabe } \\
\text { l }\end{array}$ & Mean Median & SD & $\begin{array}{c}\text { Min- } \\
\text { Mak } \\
\text { salue }\end{array}$ & $\begin{array}{c}\boldsymbol{p} \\
\text { value }\end{array}$ \\
\hline Perilaku & 18,9 & \multirow{2}{*}{19,00} & 3,31 & $13-$ & \\
Pretest & 0 & & 5 & 24 & 0,001 \\
Perilaku & 25,7 & 25,50 & 1,33 & $24-$ & \\
Posttest & 0 & & 7 & 28 & \\
\hline
\end{tabular}

Tabel 4 menunjukkan terjadi peningkatan rata-rata nilai perilaku lansia sebesar 6,80 yaitu dari 18,90 sebelum diberikan Penkes dan Latihan menjadi 25,70 setelah diberikan Penkes dan Latihan. $p=0,001<\alpha(\alpha=0,05)$ maka dapat disimpulkan bahwa ada perbedaan signifikan antara nilai rata-rata perilaku lansia sebelum dan setelah diberikan Penkes dan Latihan pada responden kelompok perlakuan.

Tabel 5. Perbedaan Kategori Perilaku Lansia Sebelum dan Setelah penkes dan latihan

\begin{tabular}{ccccc}
\hline Kategori & Pretest & $(\%)$ & Posttest & $(\%)$ \\
\hline Baik & 5 & $50 \%$ & 10 & $100 \%$
\end{tabular}




\begin{tabular}{ccccc} 
Sedang & 5 & $50 \%$ & 0 & $0 \%$ \\
\hline Total & 10 & $100 \%$ & 10 & $100 \%$ \\
\hline
\end{tabular}

Tabel 5 menunjukkan jumlah responden dengan tingkat Perilaku Lansia kategori baik bertambah dari 5 responden $(50 \%)$ menjadi 10 responden $(100 \%)$ pada kelompok perlakuan.

\section{Perilaku Lansia Kelompok Kontrol}

Tabel 6. Perbedaan Nilai Perilaku Lansia pretest dan posttest

\begin{tabular}{|c|c|c|c|c|c|}
\hline $\begin{array}{c}\text { Variabe } \\
1\end{array}$ & Mean & Median & SD & $\begin{array}{l}\text { Min- } \\
\text { Mak } \\
\text { S }\end{array}$ & $\begin{array}{c}p \\
\text { value }\end{array}$ \\
\hline $\begin{array}{c}\text { Perilaku } \\
\text { Lansia } \\
\text { Pretest }\end{array}$ & $\begin{array}{l}19, \\
30\end{array}$ & 19,00 & $\begin{array}{l}1,8 \\
89\end{array}$ & $\begin{array}{l}18- \\
24\end{array}$ & \\
\hline $\begin{array}{c}\text { Perilaku } \\
\text { Lansia } \\
\text { Posttest }\end{array}$ & $\begin{array}{l}19, \\
40\end{array}$ & 20,00 & $\begin{array}{c}2,4 \\
59\end{array}$ & $\begin{array}{l}16- \\
23\end{array}$ & 0,560 \\
\hline
\end{tabular}

Tabel 6 menunjukkan bahwa terjadi peningkatan rata-rata nilai Perilaku Lansia sebesar 0,10 yaitu dari 19,30 saat pretest menjadi 19,40 pada saat posttest kelompok kontrol dengan standar deviasi 1,889 pada pretest dan 2,459 pada posttest.

Tabel 7. Perbedaan Kategori Perilaku Lansia pretest dan posttest

\begin{tabular}{ccccc}
\hline Kategori & Pretest & $(\%)$ & Posttest (\%) \\
\hline Baik & 3 & $30 \%$ & 6 & $60 \%$ \\
$\begin{array}{c}\text { Distress } \\
\text { Sedang }\end{array}$ & 7 & $70 \%$ & 4 & $40 \%$ \\
\hline Total & 10 & $100 \%$ & 10 & $100 \%$ \\
\hline
\end{tabular}

Tabel 7 menunjukkan jumlah responden dengan tingkat Perilaku Lansia kategori baik bertambah dari 3 responden $(30 \%)$ menjadi 6 responden $(50 \%)$ pada kelompok kontrol.

Perilaku Lansia Setelah penkes dan latihan pada Kelompok Perlakuan dan Kelompok Kontrol

Tabel 8. Perbedaan Perilaku Lansia

Kelompok Perlakuan dan Kelompok Kontrol Setelah penkes dan latihan

\begin{tabular}{cccc}
\hline Variabel & $\begin{array}{c}\text { Mean } \\
\text { Difference }\end{array}$ & t & $\begin{array}{c}\boldsymbol{p} \\
\text { value }\end{array}$ \\
\hline $\begin{array}{c}\text { Difference } \\
\text { Posttest- }\end{array}$ & & & \\
$\begin{array}{c}\text { Pretest } \text { antara } \\
\text { kelompok per- } \\
\text { lakuan dan } \\
\text { kontrol }\end{array}$ & 6,300 & 7,118 & 0,001 \\
\hline
\end{tabular}

Tabel 8 menunjukkan hasil uji $t$ independent terhadap variabel beda nilai Perilaku Lansia pada kelompok perlakuan dan kelompok kontrol yaitu $\mathrm{p}=0,001(\mathrm{p}<$ $0,05)$ bahwa terdapat perbedaan signifikan nilai Perilaku Lansia antara kelompok perlakuan dan kelompok kontrol. Nilai positif pada $\mathrm{t}$ menunjukkan bahwa nilai Perilaku Lansia lebih tinggi pada kelompok perlakuan dibandingkan pada kelompok kontol. Kesimpulan dari pernyataan tersebut adalah Ha diterima dan membuktikan terdapat pengaruh yang signifikan antara penkes dan latihan terpadu terhadap Perilaku Lansia dalam pengendalian hipertensi pada lansia di Desa Serut Kecamatan Panti Kabupaten Jember.

\section{PEMBAHASAN}

Karakteristik Responden

Rata-rata umur responden pada kelompok kontrol dan intervensi adalah 64 tahun dan 63 tahun yang termasuk dalam kategori usia lansia. Usia tersebut merupakan usia yang harus menyesuaikan dengan perubahan fisik sering terjadinya penuaan sistem tubuh, perubahan penampilan dan fungsi. Perubahan yang terjadi pada lansia meliputi perubahan fisik, sosial, dan psikologis. Masalah perubahan sosial serta reaksi individu terhadap perubahan sangat beragam, bergantung pada kepribadian individu yang bersangkutan. Usia merupakan salah satu faktor yang dapat menyebabkan munculnya penyakit tekanan darah [1]. Lansia harus belajar menerima aktivitas dan minat baru untuk mempertahankan 
kualitas hidupnya akibat perubahan fisiologi pada lanjut usia adalah usia [2]. Menurut penelitian yang telah dilakukan oleh Manimuda,et al. (2011), bahwa semakin bertambahnya usia seseorang semakin berisiko terkena hipertensi .

Berdasarkan penelitian yang didapatkan, jenis kelamin responden penelitian pada kelompok control dan intervensi yaitu perempuan. Sesuai dengan penelitian Irza, bahwa prevalensi hipertensi lebih banyak pada wanita $(66,67 \%)$ dari pada laki-laki $(33,33 \%)$. Selaras dengan teori kerja hormon bahwa semakin bertambahnya usia, hormon esterogen tidak mampu menghasilkan High-Density Lipoprotein (HDL) dalam jumlah banyak, sehingga besar untuk terjadi kemungkinan aterosklerosis akibat meningkatnya Low-Density Lipoprotein (LDL). Lesi aterosklerotik ini dapat mengurangi aliran darah ke ginjal. Ginjal mengaktifkan Angiotensin II (merupakan vasokonstriktor yang kuat) dan mendorong retensi garam dan air sewaktu pembentukan urin. Sehingga volume darah bertambah untuk mengompensasi berkurangnya aliran darah ginjal. Peningkatan volume darah dan vasokonstriksi aliran darah ini sebagai penyebab meningkatnya tekanan darah arteri secara keseluruhan.

Pendidikan responden penelitian ini paling banyak yaitu SD sederajat. Pendidikan seseorang merupakan salah satu proses perubahan tingkah laku, semakin tinggi pendidikan seorang semakin banyak pula pengetahuan yang dimiliki nya, sebaliknya semakin rendah pendidikan seseorang akan menghambat perkembangan sikap seseorang terhadap nilai-nilai yang baru diperkenalkan Tingkat pendidikan lansia termasuk dalam kategori rendah, yaitu terdiri dari tidak sekolah dan tingkat sekolah dasar hal ini akan berpengaruh terhadap tingkat pengetahuan lansia terhadap penyakit yang diderita. Pendidikan dapat menjadi tolak ukur kemampuan lansia dalam berinteraksi secara efektif dan dalam jangka pendek pendidikan akan menghasilkan perubahan atau peningkatan pengetahuan individu.

\section{Perilaku lansia dalam pengendalian hipertensi Kelompok Perlakuan}

Berdasarkan hasil penelitian ini terdapat perbedaan perilaku lansia sebelum dan setelah diberikan pendkes tentang hipertensi dan program latihan terpadu. Sebelum diberikan intervensi didapatkan perilaku lansia dalam mengendalikan hipertensi yaitu $50 \%$ dalam kategori baik dan $50 \%$ dalam kategori sedang. Sedangkan setelah diberikan intervensi didapatkan $100 \%$ perilaku lansia dalam kategori baik.

Intervensi yang diberikan pada kelompok intervensi yaitu sebuah pendidikan kesehatan tentang hipertensi yang diberikan selama 4 sesi seminggu 2 kali pertemuan dan dilanjutkan seminggu satu kali program latihan yaitu senam antihipertensi. Pemberian interevensi tersebut pada kelompok perlakuan dapat menjadikan klien belajar bagaimana memecahkan masalahnya terkait hipertensi dan berperilaku sehat, sehingga pengetahuan klien terkait pengendalian hipertensi dapat meningkat. Semakin meningkat pengetahuan klien mengenai pengendalian hipertensi, maka semakin meningkat pula keberhasilannya dalam berperilaku mengendalikan hipertensi.

\section{Perilaku lansia dalam pengendalian hipertensi Kelompok Kontrol}

Berdasarkan hasil penelitian ini didapatkan bahwa ada perbedaan signifikan antara perilaku lansia dalam mengendalikan hipertensi saat pretest dan postest pada responden kelompok kontrol. Penelitian ini didapatkan peningkatan perilaku lansia dalam mengendalikan hipertensi pada kelompok kontrol.

Kelompok kontrol tidak diberikan penkes dan program latihan senam hipertensi. Klien melakukan aktivitas seperti biasa sehari-hari selama di rumah. Adanya peningkatan ini dimungkinkan oleh salah satu factor yang didapatkan dari 
hasil wawancara. Beberapa responden mengatakan bahwa sebelumnya mereka mendapatkan pendidikan kesehatan mengenai diet hipertensi dan senam antihipertensi dari tenaga kesehatan maupun mahasiswa yang pernah praktek di desanya.

\section{Pengaruh penkes dan latihan terhadap perilaku lansia dalam mengendalikan hipertensi}

Berdasarkan hasil analisa data pada Tabel 8, menunjukkan bahwa perilaku diet hipertensi mengalami peningkatan setelah diberikan penkes tentang hipertensi dan program latihan terpadu berupa senam antihipertensi dengan nilai $\mathrm{p}=0,001$ ( $\mathrm{p}<$ $0,05)$. Hal ini menunjukkan bahwa penkes tentang hipertensi dan program latihan terpadu berpengaruh terhadap peningkatan perilaku lansia dalam mengendalikan hipertensi. Pendidikan kesehatan dengan materi yang menggunakan bahasa sederhana dan mudah dipahami oleh responden dapat meningkatkan perilaku lansia dalam mengendalikan hipertensi.

Selaras dengan penelitian oleh Thiboutot, et al., bahwa pendidikan kesehatan dengan menggunakan dapat menurunkan tekanan darah serta dapat mengontrol diet pasien. Selain itu, Kelders, Pijnen, Werkman, Nijland dan Seydel menjelaskan bahwa pendidikan kesehatan menggunakan web dapat meningkatkan perilaku diet dan pengetahuan tentang perilaku yang sehat.

Penkes berisi tentang pengertian, klasifikasi, faktor penyebab, perjalanan penyakit, tanda dan gejala, faktor risiko, komplikasi, dan penatalaksanaan hipertensi, dan prosedur senam antihipertensi yang ditampilkan dengan bahasa yang mudah dipahami dan disertai gambar-gambar untuk menunjang konten informasi yang disampaikan, selain itu sumber informasi diambil dari jurnal dan text book yang telah dipadukan, sehingga mudah dipahami dan berakurasi tinggi. Setelah diberikan edukasi selama 4 sesi, diharapkan pengetahuan pasien bertambah, lalu dilanjutkan dengan sesi program latihan terpadu yang dilakukan rutin selama 4 kali (seminggu satu kali). Hal ini dilakukan dengan harapan setelah responden mendapatkan pengetahuan dapat membentuk sikap yang nantinya dapat diaplikasikan dengan sebuah perilaku sehat dalam mengendalikan hipertensi.

\section{SIMPULAN}

Simpulan dari penelitian yaitu: 1) karakteristik responden pada kelompok control dan intervensi menunjukkan rerata adalah 64 tahun dan 63 tahun; 2) Pendkes tentang hipertensi dan program latihan terpadu dapat meningkatkan perilaku lansia dalam mengendalikan hipertensi. Hal ini dikarenakan pemberian edukasi dan program latihan rutin mampu memotivasi lansia untuk lebih memperhatikan perawatan kesehatan serta dan memiliki kesadaran untuk berperilaku sesuai dengan pola hidup sehat. 3) terdapat pengaruh yang bermakna pemberian pendkes tentang hipertensi dan program latihan terpadu terhadap perilaku lansia dalam mengendalikan hipertensi dari tingkat perilaku sedang menjadi tingkat perilaku baik. $p$-value $=0,001(\alpha \leq 0,05)$.

\section{SARAN}

Penelitian ini memberikan pemahaman baru terhadap pengaruh pendkes tentang hipertensi dan program latihan terpadu terhadap perilaku lansia dalam mengendalikan hipertensi. Sehingga diperlukan adanya pemberian informasi kepada masyarakat, tenaga kesehatan, dan kader terkait hasil tersebut.

Penelitian ini juga dapat dijadikan pedoman bagi keperawatan untuk lebih giat dan aktif dalam perannya sebagai perawat komunitas untuk meningkatkan upaya promotif dan preventif bagi peningkatan derajat kesehatan keluarga melalui edukasi, dan pemeliharaan perawatan lansia yang dapat menjadi kegiatan dalam posyandu lansia. 


\section{UCAPAN TERIMA KASIH}

Penulis menyampaikan terima kasih kepada seluruh responden, dosen pembimbing, dan pihak Desa Serut Kecamatan Panti, Kabupaten Jember.

\section{KEPUSTAKAAN}

Bryant, L.L; Altpeter, M; Whitelaw, N.A. 2006. Evaluation of Health Promotion Programs for older adults: an introduction.

Cortas, K. 2008. Hypertension. Last update May 11 2008. Diakses 12 Mei 2018, dari htt p//:www.emedicine.com

Dashtbozorgi B, Chadirian F, Khajeddin N, Karami K. 2009. Effect of family psychoeducation on the level of adaptation and improvement of patients with mood disorders. Iran J Psychiat Clinical Psychol.

Firmawati, E; Rasyid, Z. M; Santosa, T. 2014. Pengaruh Blog Edukatif Tentang Hipertensi Terhadap Pengetahuan Tentang Hipertensi dan Perilaku Diet Hipertensi pada Pasien Hipertensi di Wilayah Kerja Puskesmas Wirobrajan Yogyakarta

Irza, S. 2009. Analisis Faktor Risiko Hipertensi Pada Masyarakat Nagari Bungo Tanjung, Sumatera Barat. Tesis strata satu, Universitas $\mathrm{Su}-$ matera Utara.

Kelders, S.M., Pijnen, J.E., Werkman, A., Nijland, N., \& Seydel, E.R. 2011. Eff ectiveness of a web-based in- tervention aimed at healthy dietary and physical activity behavior: a randomized controlled trial about users and usage. Journal of Medical Internet Research..

Paddison C. 2010. Familly support and conflict among aduls with type 2 diabetes. Europ Diabet Nurs.

Park, Y. H., et al. 2011.The effects of an integrated health education and exercise program in communitydwelling older adults with hypertension: A randomized controlled trial.

Sherwood, L. 2012. Fisiologi Manusia dari Sel ke Sistem (6th.ed.). Jakarta: EGC

Sugiono 2014, Statistika Untuk Penelitian, Alfabeta, Bandung.

Tanriverdi D, Ekinci M. 2012. The Effect psychoeducation intervention has on the caregiving burden of caregivers for schizophrenic patients in Turkey. Int J Nurs Pract.

Weiss J, Freeman M, Low A, et al. 2017. Benefits and harms of intensive blood pressure treatment in adults aged 60 years or older; a systematic review and meta-analysis. Ann Intern Med.

Williamson JD, Suplano MA, Aplegate WB, et al. 2016. Intensive vs standard blood pressure control and cardiovascular disease outcomes in adults aged $\geq 75$ years: a randomized clinical trial. JAMA. 